\title{
Antimalarial and Antioxidant Potentials of Extract and Fractions of Aerial Part of Borreria ocymoides DC (Rubiaceae).
}

\author{
Sunday Adeleke Adesegun, Celestina Ifeoma Orabueze, Herbert Alexander Babatunde Coker
}

\section{Sunday Adeleke Adesegun', Celestina Ifeoma Orabueze', Herbert Alexander Babatunde Coker $^{2}$ \\ 'Department of Pharmacognosy, Fac- ulty of Pharmacy, University of Lagos, P. M. B. 12003, Idi-araba, Surulere, Lagos, NIGERIA. \\ ${ }^{2}$ Department of Pharmaceutical Chem- istry, Faculty of Pharmacy, University of Lagos, P. M. B. 12003, Idi-araba, Surulere, Lagos, NIGERIA.}

\section{Correspondence}

\section{Dr. Sunday Adeleke Adesegun}

Department of Pharmacognosy, Faculty of Pharmacy, University of Lagos,

P. M. B. 12003, Idi-araba, Surulere, Lagos, NIGERIA.

Phone number: 234-803-599-5080

E-mail: sadesegun@unilag.edu.ng, asegun67@yahoo.com

\section{History}

- Submission Date: 27-9-2016;

- Review completed: 12-12-2016;

- Accepted Date: 20-12-2016.

\section{DOI : 10.5530/pj.2017.4.86}

Article Available online

http://www.phcogj.com/v9/i4

\section{Copyright}

(C) 2016 Phcog.Net. This is an openaccess article distributed under the terms of the Creative Commons Attribution 4.0 International license.

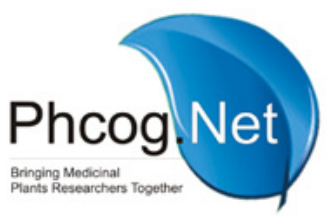

\begin{abstract}
Introduction: Borreria ocymoides (Burm F) DC is a weak, erect and decumbent herb that has several folkloric, ethno medicinal uses and is included in antimalarial preparations by some traditional healers. It is also used in treatment of ring worm, eczema and microbial infections. Objectives: To evaluate antimalarial activity of extract and fractions of Borreria ocymoides in Plasmodium berghei infected mice and to investigate their antioxidant activity using 1, 1-diphenyl-2-picryl-hydrazile (DPPH). Methods: The methanol extract of aerial part of B. ocymoides and the solvent fractions obtained from partition between organic solvents were assessed for antimalarial activity against chloroquine sensitive Plasmodium berghei NK65 infected mice using the suppressive and curative test procedures. Chloroquine $(10 \mathrm{mg} / \mathrm{ml})$ was used as positive control. The antioxidant activity was evaluated using DPPH radical scavenging ability and determination of total phenolic content. Results: The crude extract (250 and $500 \mathrm{mg} \mathrm{kg}-1$ ) produced a dose dependent anti-plasmodial activity in the suppressive and curative tests. The chemo suppression activity was best in the ethyl acetate fraction $(87.31 \%)$ and in the order ethyl acetate $>$ dichloromethane $>$ hexane $>$ aqueous fraction. The DPPH radical scavenging activity of the extract increased with concentration. The antioxidant activity was less than ascorbic acid used as positive control. Oral administration up to $5 \mathrm{~g} / \mathrm{kg}$ produced no noticeable deleterious effect 24 hours after dosing and up to 7 days afterwards. Conclusion: The results indicated that the extract has a potent anti-plasmodial activity against Plasmodium berghei and the activity seems to reside in the mid-polar fractions. Thus, the plant is a potential source of new antimalarial agents.
\end{abstract}

Key words: Antimalarial, Antioxidant, Plasmodium berghei, Borreria ocymoides, Solvent fractions.

\section{INTRODUCTION}

Malaria is an endemic infectious disease in warm climate and particularly within the less economic empowered regions of the world. ${ }^{1}$ The World Health Organization estimates that about $41 \%$ of the total world population lives in areas with malaria risk. ${ }^{2}$ This disease is caused by Plasmodium and spread out by infected female Anopheles mosquitoes called "malaria vectors" during blood meal and they bite mainly between dusk and dawn. Plasmodium species that can infect and cause disease in humans are $P$. Falciparum, $P$. malariae, $P$. ovale, and $P$. vivax. ${ }^{3}$ Plasmodium falciparum is the most virulent and is responsible for the majority of malaria related morbidity and mortality ${ }^{4}$ with significant social and economic impact in developing countries. Immunity against malaria can be naturally acquired in individuals living in malaria-endemic areas after continuous exposure to the parasite, but it seems to wane in the absence of $P$. falciparum exposure and does not give a complete protection against the infection. ${ }^{5-6}$

In Nigeria, malaria is a major primary healthcare challenge particularly for children and pregnant women. It is responsible for 30 percent childhood mortality and 11 percent maternal mortality. ${ }^{7}$ The problem is aggravated by the increasing resistant to available drugs and mosquito vectors to insecticides, resulting in high level of treatment failures. ${ }^{8-10}$ Chloroquine, a low cost drug was the first line drug of choice in Nigeria before the emergency of drug resistance and subsequent changeover to WHO approved artemisinin combination therapy (ACTs) ${ }^{6,11}$ Clinical resistance to artemisinin and its combinations was reported in some parts of the world (Cambodia and four other countries), suggesting that some $P$. Falciparum isolates have developed the ability to grow in the presence of these antimalarial agents. ${ }^{12}$ This strongly suggests the need for urgent research into new antimalarials ${ }^{13}$ with improved activity. At present there are no drugs that can completely offer protection against malaria in all regions of the world. Free radicals, such as reactive oxygen species (ROS) and nitrogen oxygen species (NOS) are molecules created when the body cells use oxygen to generate energy. These free radicals at low or moderate concentrations exert beneficial effects on cellular responses and immune function but at high levels, they induce oxidative stress, a harmful process that can damage cell structures, including lipids, proteins, 
and DNA. ${ }^{14-15}$ Oxidative stress has been implicated in the development of chronic human diseases and degenerative ailments. ${ }^{14,16-17}$ Minimizing oxidative stress could therefore ameliorate many physical ailments and help prevent certain degenerative diseases caused by free radicals. ${ }^{18}$ Antimalarial agents with both antimalarial and antioxidant activities will be an advantage in malarial treatment or prevention. ${ }^{19}$

Borreria ocymoides (Burm F) DC is a weak, erect and decumbent herb and belongs to the family Rubiaceae. ${ }^{20}$ The plant has several folkloric and ethno medicinal uses which include dermatological use in treatment of ring worm and eczema in Nigeria, antihelmintic treatment of internal worms, treatment of microbial infections (dysentery, diarrhoea, gonorrhea), aids healing of wounds, ${ }^{21}$ gastric ulcer protective potency ${ }^{22}$.The plant was also mentioned by some traditional healers in treatment of malaria. The aim of the present study is to determine anti-plasmodial and antioxidant activities of methanol extract of aerial part of Borreria ocymoides and its solvent fractions using mice infected with chloroquine sensitive Plasmodium berghei.

\section{MATERIALS AND METHODS}

\section{Plant material}

The aerial parts of B. ocymoides was collected at Ede Oballa village, Nsukka town Anambra state, Nigeria and authenticated by a retired taxonomist of University of Nigeria, Nigeria, Mr. Ozoko and confirmed by Mr. Daramola, a curator, formerly of the University Herbarium, Department of Botany, Faculty of Science, University of Lagos Akoka. The herbarium specimen was prepared and deposited with voucher number LUH 3624.

\section{Extract and fractions preparation}

The collected plant material was cleaned, air dried under shade at room temperature and powdered by using a grinding mill (Hamburg 76 West Germany). The powdered plant material $(1.3 \mathrm{~kg}$ ) was extracted exhaustively with methanol by continuous percolation in a Soxhlet apparatus. The filtrate was concentrated using a rotary evaporator under reduced pressure (Buchi Rota vapor, Germany) at $45 \mathrm{rpm}$ and $40^{\circ} \mathrm{C}$ to obtain dried crude extract $(124 \mathrm{~g})$. Extract $(100 \mathrm{~g})$ was suspended in $300 \mathrm{ml}$ distilled water and successfully fractionated with $\mathrm{n}$-hexane $(3 \times 300 \mathrm{ml})$, dichloromethane $(3 \times 300 \mathrm{ml})$ and ethyl acetate $(3 \times 300 \mathrm{ml})$ to yield $\mathrm{n}$ hexane (23.22 g), dichloromethane $(16.90 \mathrm{~g})$, ethyl acetate $(8.17 \mathrm{~g})$, and aqueous (43.28 g) fractions respectively. The extract and fractions were kept in airtight sample bottles and were stored at $4^{\circ} \mathrm{C}$ for the assays.

\section{Preliminary phytochemical screening}

The phytochemical analysis of the methanol extract of B. ocymoides was carried out to determine the presence of phenolic compounds like tannins and flavonoids, saponnins, anthraquinone derivatives, cardiac glycosides, steroidal compounds, cyanogenetic glycosides and alkaloids using standard methods. ${ }^{23-24}$

\section{Experimental animals}

Swiss albino mice (20 - 22 g) of both sexes were used for the study and were bred and kept in the Laboratory Animals Center, College of Medicine, University of Lagos, Nigeria.The animals were maintained on standard rodent feed and water ad libitum under $12 \mathrm{~h}$ light and dark cycle at room temperature. The animals were allowed to acclimatize for 14 days preceding the experiments. All experimental protocols were in compliance with internationally accepted principles for laboratory animal use and care. ${ }^{25}$

\section{Acute toxicity}

The safety of the crude extract was evaluated by determining the oral acute toxicity using a modified Lorke s method. ${ }^{26}$ The mice were starved for $24 \mathrm{~h}$ prior to drug administration. They were randomly divided into six groups of 10 mice per group (one control group and five treated groups). The control group received $0.2 \mathrm{ml}$ of $1 \%$ tween 80 , while the treated groups were given single doses of 500, 1000, 2000, 4000 and 5000 $\mathrm{mg} / \mathrm{kg}$ orally, in dose volume of $0.2 \mathrm{ml}$. The mice were observed for signs of toxicity and mortality at regular intervals for 24,48 , and $72 \mathrm{~h}$ then subsequently daily for 7 days. $^{27}$

\section{Malaria parasites}

The rodent parasite Plasmodium berghei berghei chloroquine sensitive strain (ANKA strain NK-65) was obtained from National Institute of Medical Research (NIMR), Yaba, Lagos and was maintained by continuous re-infestation in mice.

\section{Inoculum preparation}

Parasitized erythrocytes were obtained from a donor infected mouse by cardiac puncture. The inoculum was prepared by determining percentage parasitaemia and erythrocytes count of the donor mouse and diluting it with normal saline in proportions as indicated by the determinations. $^{28}$

\section{Antimalarial Analysis}

\section{Suppressive test}

The Peter's 4-day suppressive test was used to determine the suppressive activity of the extract and its fractions against chloroquine sensitive Plasmodium berghei NK 65 infection in mice. ${ }^{29}$ On first day $\left(\mathrm{D}_{0}\right)$, 24 mice were inoculated by intraperitoneal injection (i.p.) with $0.2 \mathrm{ml}$ of inoculum of Plasmodium berghei berghei containing $1 \times 10^{7}$ infected erythrocytes. The animals were randomly divided into 4 groups of six mice each and three hours later drugs were administered to the mice. Groups 1-2 received 250 and $500 \mathrm{mg} / \mathrm{kg} /$ day extract respectively, group 3 was the negative control and received $10 \mathrm{ml} / \mathrm{kg} /$ day of $1 \%$ tween $80 \mathrm{in}$ distilled water while groups 4 served as positive control received $10 \mathrm{mg} /$ $\mathrm{kg} /$ day of chloroquine. The drug administration continued daily for 4 days $\left(\mathrm{D}_{0}-\mathrm{D}_{3}\right)$ and on $5^{\text {th }}$ day $\left(\mathrm{D}_{4}\right)$ thin blood films were prepared from tail blood obtained from each mouse then stained with Giemsa to show parasitized erythrocytes out of 500 in a random field of the microscope. The above procedure was repeated for hexane, dichloromethane, ethyl acetate and aqueous fractions respectively to evaluate their antimalarial activity $(250 \mathrm{mg} / \mathrm{kg})$.

Percentage parasitaemia was calculated as

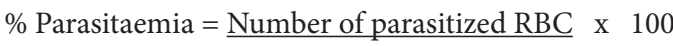

Total number of RBC counted

$\%$ Chemosuppression $=\underline{\text { APN }- \text { APT }} \times 100$

APN

Where APN is average parasitaemia in negative control and APT is average parasitaemia in test group.

\section{Curative test}

The test was carried out as described by Liu \& co workers ${ }^{30}$ with modifications. Twenty four mice were infected intrapertoneally with standard inoculum of $1 \times 10^{7}(0.2 \mathrm{ml})$ Plasmodium berghei berghei NK 65 infected erythrocytes on the first day $\left(D_{0}\right)$ and left for $72 \mathrm{~h}$ then mice were divided into 4 groups of six mice each. Groups 1-2 received orally 250 and $500 \mathrm{mg} / \mathrm{kg} /$ day extract respectively, group 3 was the negative control and received $10 \mathrm{ml} / \mathrm{kg} /$ day of $1 \%$ tween 80 in distilled water while group 4 served as positive control $10 \mathrm{mg} / \mathrm{kg} /$ day of chloroquine. The treatment 
was carried out once daily for 5 days and Giemsa's stained blood smears were prepared from the tail blood sample of each mouse collected on each day of treatment to monitor parasitaemia level. Any death that occurred during this period was noted and used to determine the mean survival time over a period of 28 days $\left(\mathrm{D}_{0}-\mathrm{D}_{27}\right)$.

\section{Antioxidant activity}

\section{DPPH radical scavenging test}

The antioxidant activity of the extract and its fractions were determined by the free radical scavenging ability using DPPH (1, 1-diphenyl-2- picrylhydrazyl) assay. ${ }^{31}$ About $1 \mathrm{ml}$ of sample solution of different concentrations $(0.05-1.0 \mathrm{mg} / \mathrm{ml})$ was mixed with $3 \mathrm{ml}$ of methanol and $1 \mathrm{ml}$ of $1 \mathrm{mM}$ DPPH in methanol was added to make up to $5 \mathrm{ml}$. The mixtures were shaken, allowed to stand at room temperature in a dark chamber for 30 minutes and the absorbance was measured at $517 \mathrm{~nm}$ using spectrophotometer. Ascorbic acid was used as positive standard control. The percentage of inhibition DPPH (\%) was calculated as follows:

$\%$ inhibition $=\underline{\text { Abs of control }- \text { Abs of test sample }} \times 100$

$$
\text { Absorbance of control }
$$

Absorbance of control

The concentration of extract leading to 50\% reduction of DPPH (IC50) was determined from the curve of $\%$ inhibitions plotted against the respective concentrations.

\section{Determination of Total Phenolic Content}

The total phenolic content of the extract was measured according to the Folin-Ciocalteu method. ${ }^{32}$ The extract solution $(0.25 \% \mathrm{w} / \mathrm{v} ; 1 \mathrm{ml})$ was mixed with $5 \mathrm{ml}$ of 1 in 10 aqueous solution of Folin-Ciocalteu reagent and $5 \mathrm{~min}$ later $4 \mathrm{ml}$ of $7.5 \% \mathrm{w} / \mathrm{v}$ sodium carbonate was added then the mixture was incubated at room temperature for $1 \mathrm{~h}$. The absorbance was measured at $760 \mathrm{~nm}$ with a spectrophotometer. Gallic acid solutions with concentration ranging from $5-200 \mu \mathrm{g} / \mathrm{ml}$ were used for calibration. A dose response linear regression was generated by using the gallic acid standard absorbance and the level in the extract was expressed as gallic acid equivalent ( $\mathrm{mg}$ of GAE/g of extract). The procedure was done in triplicate and results were expressed as mean \pm SEM.

\section{Statistical analysis:}

Results were expressed as mean \pm S.E.M. The significance of difference was determined using one-way analysis of variance (ANOVA). $\mathrm{P}<0.05$ was considered to be statistically significant.

\section{RESULTS}

\section{Preliminary phytochemical analysis}

The phytochemical screening of the crude extract of B. ocymoides indicated the presence of phenolic compounds like flavonoidsand tannins, steroidal compounds and saponins while alkaloids, cyanogenetic glycosides and anthraquinones werenot detected.

\section{Acute toxicity}

There was no mortality recorded in the mice upon oral administration even at doses as high as $5,000 \mathrm{mg} / \mathrm{kg}$. This indicates that the experimental doses used are relatively safe.

\section{Suppressive activity}

The results of the study showed that the extract displayed schizonticidal activity at the studied doses. Percentage inhibition analysis indicated that the extract produced a significant $(\mathrm{p}<0.05)$ dose-dependent decrease in parasitaemia at 250 and $500 \mathrm{mg} \mathrm{kg}^{-1}$ compared to the negative control group (Table 1). The hexane, dichloromethane and ethyl acetate fractions

Table 1: Suppressive effect of extract of $\boldsymbol{B}$. ocymoides against $\boldsymbol{P}$. berghei
infected Swiss albino mice
\begin{tabular}{|cccc}
\hline Drug & $\begin{array}{c}\text { Dose }(\mathrm{mg} / \\
\mathrm{kg})\end{array}$ & Mean Parasitaemia & $\%$ Chemosuppression \\
\hline $1 \%$ Tween 80 & & $3.13 \pm 0.11$ & - \\
Chloroquine & 10 & $0.56 \pm 0.05$ & $82.11^{*}$ \\
B. ocymoides & 250 & $1.50 \pm 0.00$ & $52.08^{*}$ \\
& 500 & $0.96 \pm 0.00$ & $69.33^{*}$ \\
\hline
\end{tabular}

Parasitaemia expressed as mean \pm SEM, $n=5$, results are expressed as the percent suppression of parasitaemia with reference to non-treated mice, ${ }^{*}$ significant difference from control at $\mathrm{p}<0.05$

Table 2: Suppressive effect of various fractions of B. ocymoides against $P$. berghei infection in mice

\begin{tabular}{cccc}
\hline Drug/Fraction & $\begin{array}{c}\text { Dose } \\
(\mathrm{mg} / \mathrm{kg})\end{array}$ & \% Parasitaemia & $\begin{array}{c}\text { \%Parasite } \\
\text { Chemosuppression }\end{array}$ \\
\hline $1 \%$ tween 80 & & $38.68 \pm 7.03$ & \\
Chloroquine & 10 & $1.76 \pm 0.08$ & $95.45^{*}$ \\
Hexane & 250 & $27.91 \pm 1.69$ & $27.84^{*}$ \\
Dichloromethane & 250 & $22.36 \pm 0.55$ & $42.19^{*}$ \\
Ethylacetate & 250 & $4.91 \pm 1.63$ & $87.31^{*}$ \\
Aqueous & 250 & $33.18 \pm 2.52$ & $14.22^{*}$ \\
\hline
\end{tabular}

Parasitaemia expressed as mean \pm SEM, $n=5$, results are expressed as the percent suppression of parasitaemia with reference to non-treated mice, * ${ }^{*}$ ignificant difference from control at $\mathrm{p}<0.05$ 
also reduced parasitaemia level significantly $(\mathrm{p}<0.05)$ compared to the negative control. The order of chemo suppression of the fractions was ethyl acetate $>$ dichloromethane $>$ hexane $>$ aqueous (Table 2).

\section{Curative activity:}

The result of the curative test showed extract of B. ocymoides demonstrated a dose- dependent reduction in mean parasitaemia $(\mathrm{p}<0.05)$ in mice by 76.2 and $84.6 \%$ at 250 and $500 \mathrm{mg} / \mathrm{kg}$ respectively like chloroquine treated groups while the negative control group showed a daily increase in parasitaemia (Table 3). Parasitaemia reduction was also observed for chloroquine, the standard drug, where reduction started from $\mathrm{D}_{1},(3.11 \%)$ to $\mathrm{D}_{5}$, where total clearance was recorded (100\%). Death did not occur in the chloroquine treated groups but occurred at 250 and 500 $\mathrm{mg} / \mathrm{kg}$ of extract at 40 and $20 \%$ respectively. The survival was $0,60,80$ and $100 \%$ for negative control, extract $250,500 \mathrm{mg} / \mathrm{kg}$ and chloroquine group respectively.

\section{Antioxidant activity}

The extract of B. ocymoides exhibited a concentration dependent DPPH radical scavenging activity which was significantly less $(\mathrm{P}>0.05)$ than ascorbic acid used as positive control with $\mathrm{IC}_{50}$ value 1.85 and 0.05 re- spectively (Figure 1). The total phenolic content of methanol extract of $B$. ocymoides was calculated as $48.0 \pm 2.49 \mathrm{mg} \mathrm{GAE} / \mathrm{g}$ of extract.

\section{DISCUSSION}

In many parts of the world where malaria is endemic, herbal preparations are used to treat the disease. Plants produce phytochemicals which have protective or preventive properties against human diseases. Antimalarial activities of many medicinal plants have been reported ${ }^{33-35}$. In this study anti-malarial activity of the extract and fractions of B. ocymoides were tested using in vivo anti-plasmodial effect against chloroquinesensitive Plasmodium berghei NK 65-infected mice. The results obtained showed that the extract elicited significant $(\mathrm{P}<0.05)$ dose dependent suppressive effect against early Plasmodium infection (suppressive effect) and established infection (curative effect) (Table $1 \& 3$ ). The extract fractions also exhibited different degrees of parasitaemia clearance in the 4-day suppressive schizontocidal activity test. The ethyl acetate and the dichloromethane fractions were found to possess higher blood schizontocidal activity ( 87.31 and $42.19 \%$ respectively) than the hexane and the aqueous fractions (27.8 and $14.22 \%$ respectively) (Table 2). This suggests the possible localization of the active ingredients in these two fractions, particularly the ethyl acetate fraction. The anti-plasmodial effect may be due to one of the active compounds of the extract or a combined effect

Table 3: Curative effect of crude extract of B. ocymoides on parasitaemia in mice

\begin{tabular}{cccccccc}
\hline Drug & $\begin{array}{c}\text { Dose }(\mathbf{m g} / \\
\mathbf{k g})\end{array}$ & Parasitaemia & DAY 1 & DAY 2 & DAY 3 & DAY 4 & DAY 5 \\
\hline $\begin{array}{c}\text { 1\% Tween } \\
80\end{array}$ & & \% Parasitaemia & $17.03 \pm 0.71$ & $19.21 \pm 0.42$ & $23.69 \pm 0.30$ & $30.21 \pm 0.22$ & $39.25 \pm 0.10$ \\
& & \% Cure & 0 & 0 & 0 & 0 & 0 \\
Crude \\
extract
\end{tabular}

Parasitaemia expressed as mean \pm SEM, $n=5$, results are expressed as the percent suppression of parasitaemia with reference to non-treated mice.

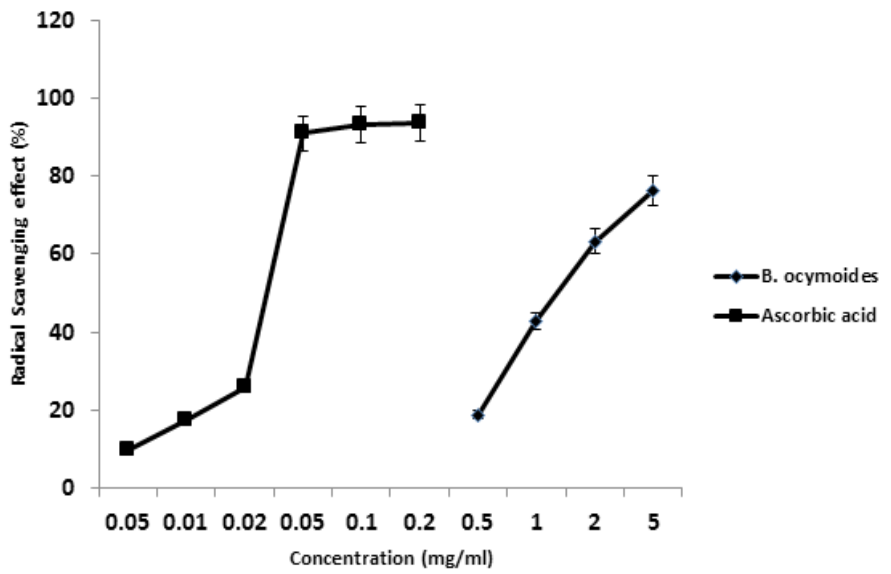

Figure 1: Radical Scavenging Effects of B. ocymoides and Ascorbic acid on DPPH Radical 
of many. Previous studies on individual effects of Cinchona alkaloids and synergistic effect between the various alkaloids has shown improved activity over quinine against resistant $P$. falciparum in vitro, ${ }^{36}$ particularly when quinine is combined with cinchonine. ${ }^{37}$ The synergistic effects of the active compounds has numerous benefit since it could lead to enhanced efficacy, decreased dosage or increased level of target inhibition, reduced or delayed development of drug resistance and reduction of toxic effects. ${ }^{38}$

The Rane's test evaluates the curative ability of compounds on established infection and is commonly used for antimalarial drug screening. In this test, extract of B. ocymoides has better parasitaemia clearance than in the suppressive test. In the 4-day suppressive study, the percentage parasitaemia was lower (69.33\%) at the dose of $500 \mathrm{mg} / \mathrm{kg}$ than the reduction recorded in the curative test $(84.61 \%)$ at the same dose. This lower activity may probably be due to specificity of the crude extract on established infection. The mean survival time of the infected mice was prolonged as $20 \%$ death was observed at higher dose of the extract increased while $100 \%$ mice-mortality occurred in the untreated control.

The study on acute toxicity revealed absence of mortality even up to the dose of $5000 \mathrm{mg} / \mathrm{kg}$ body weight of extract administered orally, which indicates the safety of the extract at the various test doses.

The preliminary phytochemical analysis of the crude extract of $B$. ocymoides showed the presence of phenolics, steroidal compounds and saponins. Phenolic compounds like flavonoïds and tannins are good antioxidant substances which have been reported to have biological activities and prevent or control oxidative stress related disorders. ${ }^{39}$ The crude extract tested negative to alkaloids. This finding is contrary to report of Conserva and Ferreira et al. in 2012 that alkaloids were present in species of Borreria. ${ }^{40}$ Previous studies indicated that many phenolic and steroidal compounds possessed anti-plasmodial activities. ${ }^{41-43}$

Malarial pathogenesis was reported to be associated with free radicals formation and decrease of antioxidant level. ${ }^{17,}{ }^{44-45}$ This suggests that an increase in the body antioxidant can initiate the decrease in parasite number and severe infection at the long run. ${ }^{17,46}$ Oxidative stress has been implicated in the pathophysiology of malaria. ${ }^{47}$ The efficacy of antioxidants is usually associated with their ability to inhibit oxidative damage by scavenging free radicals. ${ }^{48} \mathrm{DPPH}$ is a very useful reagent for investigating free radical scavenging ability of compounds. B. ocymoides extract demonstrated good antioxidant activity by reducing the purple colored DPPH radical solution to yellow colored diphenylhydrazine due to the presence of hydrogen-donating antioxidants. ${ }^{49}$ The extract also has phenolic compounds that are antioxidant agents which also act as free radical terminators. ${ }^{50}$ The Folin-Ciocalteau reagent method used measures the level of oxidizable or phenolic compounds in the extract. ${ }^{51}$ Phenolic compounds are considered to be the most important antioxidative plant components and the antioxidant activity of plant extracts correlates with the content of their phenolic compounds. ${ }^{52-53}$ The phenolic compounds in the extract may be involved in the antimalarial activity exhibited by the B. ocymoides crude extract. The antimalarial activity of phenolic compounds was reported to be due to elevation of red blood cell oxidation, inhibition of parasite's protein synthesis and also by counteracting the oxidative damage induced by the malaria parasite ${ }^{47}$ Plants and compounds with antioxidant activity may ameliorate the progress of malarial infection and possibly prevent the development of cerebral complications and other malaria related complications. ${ }^{54}$ However, the challenge here is that some antimalarial drugs generate the free radicals to produce their effect suggesting that their activity may be reduced in the presence of antioxidants. The anti-plasmodial activity observed in this study is consistent with the traditional use of the B. ocymoides as herbal medications against malaria in Nigeria.

\section{CONCLUSION}

This study indicates that methanol extract and solvent fractions of $B . o c y$ moides have good anti-plasmodial and antioxidant activities. The extract appeared to be superior in curative parasitaemia reduction than suppressive activity. The findings suggested that the phytochemicals responsible for antimalarial activity of the plant are polar in nature with antioxidant properties. Future studies on the plant regarding antimalarial activity should be conducted to isolate compounds responsible.

\section{ACKNOWLEDGEMENT}

The authors are grateful to University of Lagos and Tertiary Education Tax Fund (TETFUND), Nigeria for financial support CRC/TETFUND/ No.2011/18. We also appreciate Mr. D. Ota of Department of Physiology, College of Medicine, University of Lagos, Nigeria for his assistance in animal studies.

\section{CONFLICT OF INTEREST}

The authors declare that there is no conflict of interest regarding the publication of this research paper.

\section{ABBREVIATIONS USED}

DPPH: 1,1-diphenyl-2-picrylhydrazyl; GAE: Gallic acid equivalent; ANOVA: Analysis of variance.

\section{REFERENCES}

1. Tesfaye WH, Alamneh EA. In vivo antimalarial activity of the crude extract and solvent fractions of the leaves of Zehenria scabra (Cucurbitaceae) against Plasmodium berghei in mice. Journal of medicinal plant research 2014;8(42):123036.

2. WHO. World Malaria Report 2012;195, WHO, Press, Geneva, Switzerland. Geneva

3. Nmadu PM, Pete E, Alexander P, Koggie AZ, Maikenti JI. The Prevalence of Malaria in Children between the Ages 2-15 Visiting Gwarinpa General Hospital Life-Camp, Abuja, Nigeria. Journal of Health Science 2015;5(3):47-51.

4. WHO. Epidemiology of severe Falciparum malaria, Tropical Medicine \& International Health 2014;19:131. PMid:24851262.

5. Doolan DL, Dobano C, Baird JK. Acquired immunity to malaria. Clinical Microbiology Reviews 2009;22(1):13-36. https://doi.org/10.1128/CMR.00025-08 ; PMid:19136431 PMCid:PMC2620631.

6. WHO. Global report on antimalarial drug efficacy and drug resistance: 2000 2010. WHO malaria factsheet 2010;121.

7. Katsayal UA, Obamiro KO. In-vivo anti-plasmodial activity and phytochemical screening of ethanolic extract of the leaves of Cissampelos mucronata. Nigerian Journal of Pharmaceutical Sciences 2007;6(2):819-23

8. Omosa LK, Okemwa EK. Anti-plasmodial Activities of stem bark extract and compounds of Zanthoxylum gilletii (De wild) P.G. Waterman. Phramcognosy communications 2017;7(1):41-6. https://doi.org/10.5530/pc.2017.1.6.

9. Matuscheski K. Vaccine development against malaria. Current Opinion in Immunology 2006; 18(4):449-57. https://doi.org/10.1016/j.coi.2006.05.004 ; PMid:16765576

10. Apponte JJ, Aide P, Renom M. Safety of the RTS, S/ASO2D candidate malaria vaccine in infants living in a highly endemic area of Mozambique: a double blind randomized controlled phase I/II b. Lancet 2007;6(7):1542-6.

11. WHO. Update on artemisinin resistance. Global Malaria Programme 2012; No 10. WHO, Press, Geneva, Switzerland. Geneva.

12. Wongsrichanalai C, Meshnick SR. Declining artesunate-mefloquine efficacy against $P$. falciparum malaria on the Cambodian Thai border. Emerging Infectious Diseases 2008;14(5):716-9. https://doi.org/10.3201/eid1405.071601 ; PMid:18439351 PMCid:PMC2600243.

13. Noedl H, Se Y, Schaecher K, Smith BL, Socheat D, Fukuda MM. Evidence of artemisinin-resistant malaria in western Cambodia. New England Journal of Medicine 2008;359(24):2619-20. https://doi.org/10.1056/NEJMc0805011 PMid:19064625.

14. Pham-Huy LA, He H, Pham-Huyc C. Free radicals, antioxidants in disease and health. International Journal of Biomedical Science 2008;4(2):89-96. PMid:23675073 PMCid:PMC3614697.

15. Pino P, Vouldoukis I, Dugas N, Hassani- Loppion G, Dugas B, Mazier D. Redox dependent apoptosis in human endothelial cells after adhesion of Plasmodium Falciparum-infected erythrocytes. Annals of the New York Academy of Sciences 
2003; 1010:582-6. https://doi.org/10.1196/annals.1299.109 ; PMid:15033796.

16. Willcox JK, Ash L, Catignani GL. Antioxidants and prevention of chronic disease. Critical Reviews in Food Science and Nutrition 2004;44(4):275-95. https:// doi.org/10.1080/10408690490468489; PMid:15462130.

17. Kronenberger T, Lindner J, Meissner KA, Zimbres FA, Coronado MA, Sauer FM, Schettert B, Wrenger C. Vitamin B6- dependent enzymes in the human malaria parasite Plasmodium Falciparum: A druggable target? BioMed Research International. 2014;1-11. https://doi.org/10.1155/2014/108516 ; PMid:24524072 PMCid:PMC3912857.

18. Iyawe HOT, Onigbinde AO. The role of ascorbic acid in the treatment of Plasmodium berghei infected mice. African Journal of Biochemical Research. 2009;3(11):375-8.

19. Ayoola GA, Coker HAB, Adesegun SA, Adepoju-Bello AA, Obaweya K, Ezennia EC, Atangbayila TO. Phytochemical screening and antioxidant activities of some selected medicinal plants used for malaria therapy in Southwestern Nigeria. Tropical Journal of Pharmaceutical Research. 2008;7(3):1019-24.

20. Burkill HM. The Useful Plants of West Tropical Africa, Vol.4, Fam. M-R, Kew:Royal Botanical Garden. 1997;625.

21. Conserva LM, Ferreira JC. Borreria and Spermacoce species (Rubiaceae): A review of their ethnomedicinal properties, chemical constituents, and biological activities. Pharmacognosy Review. 2012:6(11):46-55. https://doi. org/10.4103/0973-7847.95866 ; PMid:22654404 PMCid:PMC3358967.

22. Okwuosa CN, Nwachukwu DC, Achukwu PUO, Ezeorah CG, Eze AA. Anti-ulcer activity of the leaf extracts of Borreria ocymoides in rats. African Journal Online 2009;7(1):20-5. https://doi.org/10.4314/br.v7i1.45471.

23. Onawumi OO, Adelowo FE, Ipaedeola AO, Edewor TI, Ayoola PB, Odunola OA. Preminary studies on phytochemical and antimicrobial investigation of plants (Irawo-ile) Mitracar pusvillosus, Euphorbia hirta and Spermacore ocymoides. International Journal of Research and Reviews in Applied Sciences 2012;10:78-81.

24. Sofowora AE. Medicinal plants and traditional medicines in Africa. 2ndEdition. Spectrum Books, Ibadan, Nigeria 1993;289.

25. NIH-National Institutes of Health. Guide for the Care and Use of Laboratory Animals: DHEW Publication (NIH), revised. Office of Science and Health Reports, DRR/NIH, Bethesda, USA, 1985

26. Lorke D. A new approach o practical acute toxicity test. Archives of Toxicology. 1983;54(4):275-86. https://doi.org/10.1007/BF01234480 ; PMid:6667118.

27. Burger C, Fischer DR, Cordenunzzi DA, Batschauer de Borba AP, Filho VC, Soares dos Santos AR. Acute and subacute toxicity of the hydroalcoholic extract from Wedelia paludosa (Acmela brasilinsis) (Asteraceae) in mice. Journal of Pharmaceutical Science 2005;8:370-3.

28. Muthaura CN, Rukung GM, Chhabra SC, Omar SA, Guantai AN, Gathirwa CW, Munzai GM, Njagi NME. Antimalarial activity of some plants traditionally used in treatment of malaria in Kwale district of Kenya. J Ethnopharmacol. 2007; 112:545:51.

29. Peters W, Portus JH, Robinson BL. The chemotherapy of rodent malaria, XXII. The value of drug-resistant strains of $P$. berghei in screening for blood schizontocidal activity. Ann. Trop. Med Parasitol. 1975;69(2):155-71. https://doi.org/10.1 080/00034983.1975.11686997.

30. Liu KC, Yang SL, Roberts MF, Elford BC, Phillipson JD. Antimalarial activity of Artemisia annua flavonoids from whole plants and cell cultures. Plant Cell Rep. 1992; 11(12):637-40. https://doi.org/10.1007/BF00236389 ; PMid:24213368.

31. Mensor L, Menezes F, Leitao G, Reis A, Santos T, Coube C, Leitao S. Screening of Brazilian plant extracts for antioxidant activity by the use of DPPH free radical method. Phytotheraphy Research 2001; 15: 127-130. https://doi.org/10.1002/ ptr.687 ; PMid:11268111.

32. Rahmat AK, Muhammad RK, Sumaira S, Mushtaq A. Evaluation of the phenolic content and antioxidant activity of various extracts of Sonchus asper L. Chemistry Journal 2011;6(12):43-8.

33. Mustofa EN, Sholikha E, Wahynono S. In vitro and in vivo anti-plasmodial activity and cytotoxicity of extracts of Phyllanthus niruri L. herbs, traditionally used to treat malaria in Indonesia. Southeast Asian J. Trp. Med. Public Health 2007;38(4):609-15

34. Mumingsih TH, Subeki K, Matsura M, Takabashi O, Yamato K, Maede M, Katakura S, Suzuki K, Yoshihara T. Evaluation of the inhibitory activities of the extracts of Indonesian traditional medicinal plants against Plasmodium Falciparum and Babesia gibsoni. J. Vet. Med. Sci. 2005;67(8):829-31. https://doi. org/10.1292/jvms.67.829

35. Adebayo JO, Kretti AU. Potential anti-malarial from Nigeria plants: A review. J. Ethnopharmacol. 2011;133:289-302. https://doi.org/10.1016/j.jep.2010.11.024

\section{; PMid:21093570}

36. Knauer A, Sirichaisinthop J, Reinthaler FF, Wiedermann G, Wernsdorfer G, Wernsdorfer WH. In-vitro response of Plasmodium Falciparum to the main alkaloids of Cinchona in northwestern Thailand. Wien KlinWochenschr 2003;115(Suppl 3):39-44. PMid:15508779

37. Druilhe $\mathrm{P}$, Brandicourt $\mathrm{O}$, Chongsuphajaisiddhi T, Berthe J. Activity of a combination of three Cinchona bark alkaloids against Plasmodium Falciparum in vitro. Antimicrobial Agents Chemotherapy 1988;32(2):250-4. https://doi.org/10.1128/ AAC.32.2.250 ; PMid:3284455 PMCid:PMC172144.

38. Ginsburg H, Deharo E. A call for using natural compounds in the development of new antimalarial treatments - an introduction. Malaria Journal 2011;10(Suppl 1):S1 https://doi.org/10.1186/1475-2875-10-S1-S1 ; PMid:21411010 PMCid:PMC3059457.

39. Naskar S, Islam A, Mazumder UK, Saha P, Haldar PK, Gupta M. In vitro and in vivo antioxidant potential of hydromethanolic extract of Phoenix dactylifera fruits, Journal Scientific Research, 2010;2(1):144-57.

40. Conserva LM, Ferreira JC. Borreria and Spermacoce species (Rubiaceae): A review of their ethnomedicinal properties, chemical constituents, and biological activities. Pharmacogn Rev. 2012:(6)11:46-55. https://doi.org/10.4103/09737847.95866 ; PMid:22654404 PMCid:PMC3358967.

41. Laphookhieo S, Maneerat W, Koysomboon S. Antimalarial and cytotoxic phenolic compounds from Cratoxylum maingayi and Cratoxylum cochinchinense. Molecule 2009;14(4):1389-95. https://doi.org/10.3390/molecules14041389 PMid:19384270.

42. Kusch P, Deinninger S, Specht S, Maniako R, Haubrich S, Pommerening T, $\mathrm{Li}, \mathrm{P}$, Hoerauf $\mathrm{A}$, Kaiser, A. In vitro and in vivo antimalarial activity assays of seeds from Balanites aegyptiaca: Compounds of the extract show growth inhibition and activity against Plasmodial aminopeptidase. Journal of Parasitology Research 2011;1-9. https://doi.org/10.1155/2011/368692; PMid:21687598 PMCid:PMC3112518.

43. Beroa J, Fre'de' richb M, lleQuetin-Leclercqa J. Antimalarial compounds isolated from plants used in traditional medicine. Journal for Pharmacy and Pharmacology 2009;61:1401-33. https://doi.org/10.1211/jpp.61.11.0001.

44. Becker K, Tilley L, Vennerstrom JL, Roberts D, Rogerson S, Ginsburg H. Oxidative stress in malaria parasite infected erythrocytes: Host-parasite interactions. International Journal of Parasitolgy. 2004;34(2):163-89. https://doi.org/10.1016/j. ijpara.2003.09.011; PMid:15037104

45. Muller S. Redox and antioxidant systems of the malaria parasite Plasmodium Falciparum. Molecular Microbiology. 2004;53(5):1291-305. https://doi. org/10.1111/j.1365-2958.2004.04257.x ; PMid:15387810.

46. Bozdech Z, Gisburg H. Antioxidant defense in Plasmodium Falciparum data mining of the transcriptome. Malaria Journal 2004;3(1):23. https://doi. org/10.1186/1475-2875-3-23 ; PMid:15245577 PMCid:PMC514526.

47. Builders MI, Wannang NN, Ajoku GA, Builders PF, Orisadipe A, Aguiyi JC. Evaluation of antimalarial potential of Vernonia ambigua Kotschy and Peyr (Asteraceae). International Journal of Pharmacology 2010;18(11):1-9

48. Perc'ario S, Moreira DR, Gomes BAQ. Oxidative stress in malaria. International Journal of Molecular Sciences 2012;13(12):16346-72. https://doi.org/10.3390/ ijms131216346; PMid:23208374 PMCid:PMC3546694.

49. Shon MY, Kim TH, Sung NJ. Antioxidants and free radical scavenging activity of Phellinus baumii (Phellinus of Hymenochaetaceae) extracts. Food Chem. 2003: 82: 593-597. https://doi.org/10.1016/S0308-8146(03)00015-3.

50. Shahidi F, Wanasundara PKJPD. Phenolic antioxidants. Crit. Rev. Food Sci. Nutr. 1992;32(1):67-103. https://doi.org/10.1080/10408399209527581; PMid:1290586.

51. Wangensteen $H$, Samuelsen $A B$, Malterud KE. Antioxidant activity in extracts from coriander. Food Chem. 2004; 88(2):293-7. https://doi.org/10.1016/j.foodchem.2004.01.047.

52. Hu M, Skibsted LH. Antioxidative capacity of rhizome extract and rhizome knot extract of edible lotus (Nelumbo nuficera). Food Chemistry 2002;76(3):327-33. https://doi.org/10.1016/S0308-8146(01)00280-1.

53. Leong LP, Shui G. An investigation of antioxidant capacity of fruits in Singapore markets. Food Chemistry 2002;76(1):69-75. https://doi.org/10.1016/S03088146(01)00251-5.

54. Reis PA, Comim CM, Hermani F, Silva B, Barichello T, Portella AC, Gomes FC, Sab IM, (2010): Cognitive dysfunction is sustained after rescue therapy in experimental cerebral malaria, and is reduced by additive antioxidant therapy," PLoS Pathogens, 6: e1000963. https://doi.org/10.1371/journal.ppat.1000963 PMid:20585569 PMCid:PMC2891838 


\section{SUMMARY}

- Borreria ocymoides plant is a widely used in traditional medicine in Nigeria to treat ring and internal worms, microbial infections, wounds, ulcer and malaria.

-Attempt has been made to establish anti-plasmodial and antioxidant activities of the plant

-Extract of B. ocymoides exhibited potent anti-plasmodial activity against Plasmodium berghei and the activity seems to reside more in the mid-polar fractions.

\section{ABOUT AUTHORS}

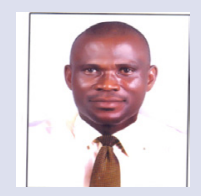

Dr. S. A. Adesegun: is an Associate Professor in the Department of Pharmacognosy, Faculty of Pharmacy, University of Lagos, Nigeria.

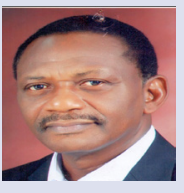

Herbert Alexander Babatunde Coker: A professor in the Department of Pharmaceutical Chemistry, Faculty of Pharmacy, University of Lagos, Nigeria.

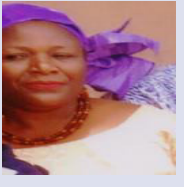

Celestina Ifeoma Orabueze: A lecturer in the Department of Pharmacognosy, Faculty of Pharmacy, University of Lagos, Nigeria.

Cite this Article: Adesegun SA, Orabueze Cl, Coker HAB. Antimalarial and Antioxidant Potentials of Extract and Fractions of Aerial part of Borreria ocymoides DC (Rubiaceae). Pharmacogn J. 2017;9(4): 534-40. 